\title{
Seni sebagai Media Dakwah Pembinaan Akhlak
}

\author{
Raga Bagus Satriya \\ Komunikasi Penyiaran Islam, Pascasarjana UIN Sunan Ampel, \\ Surabaya. Indonesia \\ ragasatria99o@gmail.com
}

\begin{abstract}
The As-Salim art boarding school is known as the "art" hut, because the students there have various abilities and skills. The students were fostered by KH. Miftachul Munir majority are orphans, who are usually synonymous with "naughty". From the mischief, KH. Miftachul Munir tried to draw their attention to the field of art with Islamic nuances. This research is a qualitative research. Data collected by observation, interviews, and documentation. With qualitative descriptive data analysis, and phenomenology approach. The results of the study show that 1) KH. Miftachul Munir in carrying out his indictment activities used media preaching arts. The process of his da'wah in fostering santri morality began with his efforts to establish As-Salim Islamic boarding school. 2) The advantages of the art media preaching are still very rarely applied by the public in santri moral formation. While the drawback is that not all da'i are able to implement it.
\end{abstract}

\section{Keywords: Art, Da'wah Media, Moral Development}

\begin{abstract}
Abstrak. Pondok pesantren seni As-Salim dikenal sebagai pondok "seni" karena para santri memiliki kemampuan dan keterampilan yang bermacam-macam, mulai seni lukis hingga seni musik. Para santri yang dibina oleh KH. Miftachul Munir mayoritas adalah anak yatim, yang biasanya identik dengan kata "nakal". Dari kenakalan tersebut, KH. Miftachul Munir mencoba menarik perhatian mereka pada bidang seni yang bernuansa Islami. Penelitian ini merupakan penelitian kualitatif. Pengumpulan data dilakukan dengan observasi, wawancara, dan dokumentasi. Dengan analisis data deskriptif kualitatif dan pendekatan fenomenologi, penelitian menunjukkan bahwa 1) KH. Miftachul Munir dalam melaksanakan aktivitas dakwahnya menggunakan media dakwah seni, yakni seni musik dan seni lukis islami. Proses dakwah KH. 2) Kelebihan media dakwah seni adalah masih sangat jarang diaplikasikan oleh khalayak dalam pembinaan akhlak santri, sedangkan kekurangannya adalah tidak semua da’i mampu menerapkannya.
\end{abstract}

Kata Kunci: Seni, Media Dakwah, Pembinaan Akhlak 


\section{Pendahuluan}

Dalam bahasa Inggris, media merupakan bentuk jamak dari medium yang berarti tengah, antara, rata-rata. Dari pengertian ini, ahli komunikasi mengartikan media sebagai alat yang menghubungkan pesan komunikasi yang disampaikan oleh komunikator kepada komunikan (penerima pesan). Dalam bahasa Arab, media sama dengan washilah atau dalam bentuk jamak, wasail yang berarti alat atau perantara (Aziz, 2004: 403).

Media adalah alat atau sarana yang digunakan untuk menyampaikan pesan komunikator kepada khalayak (Cangara, 2000:131). Wilbur Schramm dalam bukunya Big media Little Media 1977, mendefinisikan media sebagai teknologi informasi yang dapat digunakan dalam pengajaran (Amin, 2009:113). Secara bahasa arab, media/wasilah berarti alwushlah, at attishad, yaitu segala hal yang dapat menghantarkan terciptannya kepada sesuatu yang dimaksud (Enjang, 2009: 93).

Dari beberapa pendapat di atas, dapat diberikan pengertian secara rasional bahwa media dakwah adalah segala sesuatu yang dipergunakan atau menjadi menunjang dalam berlansungnya pesan dari komunikan (da'i) kepada kalayak. Dengan kata lain, segala sesuatu yang dapat menjadi penunjang/alat dalam proses dakwah yang berfungsi mengefektifkan penyampaian ide (pesan) dari komunikator (da’i) kepada komunikan (khalayak).

Dakwah merupakan proses yang berkesinambungan yang ditangani oleh para pengembang dakwah untuk mengubah sasaran dakwah agar bersedia masuk ke jalan Allah, dan sasaran bertahap menuju pada kehidupan yang Islami (Hafiduddin, 1998:77). Suatu proses yang berkesinambungan adalah suatu proses yang bukan insidental atau kebetulan, melainkan benar-benar direncanakan, dirumuskan, dan dievaluasi secara terus menerus oleh pengembang dakwah dalam rangka mengubah perilaku sasaran dakwah sesuai dengan tujuan-tujuan yang telah direncanakan atau dirumuskan.

Ada dua segi dakwah yang tidak dapat dipisahkan, tetapi dapat dibedakan, yaitu menyangkut isi dan bentuk, substansi dan forma, pesan dan cara penyampaiannya, esensi dan metode (Aras, 2006:14-16). Proses dakwah menyangkut kedua-duanya sekaligus dan tidak terpisahkan. Hanya saja, perlu disadari bahwa isi, substansi, pesan, dan esensi senantiasa mempunyai dimensi universal yang tidak terikat oleh ruang dan waktu. Dalam hal ini, substansi dakwah adalah pesan keagamaan itu sendiri. Itulah sisi pertama dalam dakwah. Sisi kedua, meskipun tidak kurang pentingnya dalam dakwah, yakni sisi bentuk, forma, cara penyampaian dan metode.

Sebuah media dakwah juga penting untuk dimengerti didalam proses komunikasi dakwah (Muriah, 2000: 1213). Membicarakan media dakwah, tentunya tidak lepas dari metode yang digunakan dalam melakukan dakwah. Pengembangan metode dakwah sangat berkait dengan media yang menyertainya. Seorang $d a \imath$, misalnya, harus mampu memilih media dakwah yang relevan dengan kondisi mad'u yang telah dipelajari secara komprehensif dan berkesinambungan. Kegiatan dakwah yang dilakukan dengan mempertimbangkan kondisi audiens tersebut akan lebih memberikan hasil yang jelas.

Dalam perkembangan dakwah Islam, pondok pesantren merupakan lembaga pendidikan Islam yang mempunyai peran dalam mengembangkan aktivitas dakwah. Ini dapat dilihat dari dua 
fungsi utama pondok pesantren, yaitu sebagai pusat pendidikan dan penyiaran agama Islam. Sepanjang sejarah perjalanan umat Islam (Indonesia), ternyata kedua fungsi utama tersebut telah dilaksanakan oleh pondok pesantren (pada umumnya) dengan baik meskipun dengan berbagai kekurangan yang ada. Dari pondok pesantren, lahir para juru dakwah, para mu'alim, ustadz, para kiai pondok pesantren, tokoh-tokoh masyarakat, bahkan yang memiliki profesi sebagai pedagang, pengusaha ataupun bidangbidang lainnya.

Pondok pesantren seni As-Salim yang berlokasi di kabupaten Sidoarjo memiliki peran aktif dalam melakukan dakwah Islam. Pondok pesantren seni AsSalim dikenal sebagai pondok "seni" karena para santri di sana memiliki kemampuan dan keterampilan yang bermacam-macam, mulai dari seni lukis dan seni musik. Ini semua tidak luput dari intervensi dakwah pimpinan pondok (KH. Miftachul Munir) yang turut membina dan mendidik santri guna menjadi manusia yang kreatif sekaligus bertakwa kepada Allah SWT.

Dari seni lukis, para santri yang memiliki potensi berkarya melalui lukisan diarahkan untuk mempelajari seni lukis yang berkaitan dengan nilai islami. Seperti halnya seni kaligrafi, ornament islami, dan lain sebagainya. Anak-anak yang memiliki potensi bemusik diarahkan kepada aliran musik yang berbau religi, seperti musik banjari, nasyid, dan lain sebagainya. Berdasarkan fenomena tersebut, penelitian ini berusaha mengungkapkan bagaimana proses penerapan media dakwah seni dalam membina akhlak santri, dan bagaimana kelebihan dan kekurangan media dakwah seni dalam membina akhlak santri selama perjalanan dakwah yang dijalankan oleh KH. Miftachul Munir?

\section{Metode Penelitian}

Metode penelitian yang digunakan dalam penelitian ini adalah metode kualitatif. Jenis Pendekatan yang digunaka adalah fenomenologi, yaitu berusaha untuk mengungkap dan mempelajari serta memahami suatu fenomena beserta konteksnya yang khas dan unik yang dialami oleh individu hingga tataran keyakinan individu yang bersangkutan. Subjek penelitian ini adalah media dakwah KH. Miftahul Munir. Dan lokasi penelitian berada di Pondok Pesantren Seni As-Salim Jalan Raya Kemiri RT. 02 RW. 01 No.79 Kabupaten Sidoarjo.

Menurut Lofland, sumber data utama pada penelitian kualitatif berupa kata-kata dan tindakan. Selebihnya adalah data tambahan seperti dokumen, dan lainlain (Moleong, 2003:157). Jenis data yang digunakan oleh peneliti dibagi menjadi dua, yakni data primer dan data sekunder. Data Primer adalah data yang diperoleh langsung dari sumber asli, dalam hal ini peneliti memperoleh dari hasil wawancara dengan KH. Miftachul Munir sebagai key informan. Alasan peneliti menggunakan data primer adalah karena dengan adanya data itu peneliti dengan mudah mendapatkan informasi langsung tentang masalah yang diangkat.

Data sekunder merupakan data yang diperoleh secara tidak langsung melalui media perantara dan merupakan data pelengkap dan pendukung. Alasan peneliti menggunakan data sekunder adalah bahwa mencari informasi tentang masalah yang diangkat dalam penulisan skripsi ini tidak hanya melalui wawancara langsung dengan para informan, tetapi juga bisa dengan media yang lain. Sepertihalnya dokumentasi kegiatan dakwah KH. Miftachul Munir, data yang berasal dari berbagai sumber-sumber literatur yang terkait. 
Analisis data dalam penelitian kualitatif menggunakan metode induktif. Penelitian ini tidak menguji hipotesis (akan tetapi hipotesis kerja hanya digunakan sebagai pedoman) tetapi lebih merupakan penyusunan abstraksi berdasarkan data yang dikumpulkan. Analisis dilakukan lebih intensif setelah semua data yang diperoleh di lapangan sudah memadai dan dianggap cukup, untuk diolah dan disusun menjadi hasil penelitian sampai dengan tahap akhir yakni kesimpulan penelitian. Analisis data dalam penelitian kualitatif dilakukan sejak sebelum memasuki lapangan, selama di lapangan, dan setelah selesai di lapangan. Menurut Nasution (dalam Sugiyono, 2008: 245), analisis telah mulai sejak merumuskan dan mejelaskan masalah, sebelum terjun ke lapangan, dan berlangsung terus sampai penulisan hasil penelitian.

\section{Hasil dan Pembahasan}

Dakwah sebagai suatu kegiatan komunikasi keagamaan dihadapkan kepada perkembangan dan kemajuan teknlogi komunikasi yang semakin canggih, memerlukan suatu adapasi terhadap kemajuan itu. Artinya dakwah dituntut untuk dikemas dengan terapan media komunikasi sesuai dengan aneka mad'u (komunikan) yang dihadapi (Ghazali, 1997:33). Laju perkembangan zaman berpacu dengan tingkat kemajuan ilmu pengetahuan dan teknologi, tidak terkecualli teknologi komunikasi yang merupakan suatu sarana yang menghubungkan suatu masyarakat dengan masyarakat di bumi lain. Kecanggihan teknologi komunikasi ikut mempengaruhi seluruh aspek kehidupan manusia termasuk di dalamnya kegiatan dakwah sebagai salah satu pola penyampaian informasi dan upaya transfer ilmu pengethauan.
Hal tersebut menunjukkan bahwa proses dakwah bisa terjadi dengan menggunakan berbagai sarana/media, karena perkembangan ilmu pengetahuan dan teknologi sangat memungkinkan hal itu. Ilmu pengetahuan dan teknologi sangat berdampak positif sebab dengan demikian pesan dakwah dapat menyebar sangat cepat dengan jangkauan dan tempat yang sangat luas pula. Dalam suatu proses dakwah, seorang juru dakwah ( $d a$ ’i) dapat menggunakan berbagai sarana atau media. Salah satu unsur keberhasilan dalam berdakwah adalah kepandaian seorang $d a \dddot{i}$ dalam memilih dan menggunakan sarana atau media yang ada (Sasono, dkk, 1998:154).

Dengan banyaknya media yang ada, maka $d a \dddot{i}$ harus dapat memilih media yang paling efektif untuk mencapai tujuan dakwah. Di sini, masalahnya adalah memilih. Memilih tentu saja mengandung konsekuensi mengetahui dan menguasai cara memanfaatkan potensi yang dipilihnya, dan bukannya memilih untuk disimpan atau dibiarkan saja.

Pada dasarnya, komunikasi dakwah dapat menggunakan berbagai media yang dapat merangsang indera-indera manusia serta dapat menimbulkan perhatian untuk dapat menerima dakwah. Berdasarkan banyaknya komunikan yang menjadi sasaran dakwah, diklasifikasikan menjadi dua, yaitu media massa dan media nonmassa. Hamzah Ya'qub (dalam Aziz, 2004:120) membagi media dakwah itu menjadi lima, yakni Lisan. Ini media dakwah yang paling sederhana yang menggunakan lidah dan suara. Media ini dapat berbentuk pidato, ceramah, kuliah, bimbingan, penyuluhan, dan sebagainya. Tulisan. Buku majalah, surat kabar, korespondensi (surat, e-mail, sms), spanduk dan lain-lain. Lukisan, gambar, karikatur, dan sebagainya. Audio visual. Alat dakwah yang dapat merangsang 
indera pendengaran atau penglihatan dan kedua-duanya. Bisa berbentuk televisi, slide, OHP, internet, dan sebagainya. Akhlak. Perbuatan-perbuatan nyata yang mencerminkan ajaran Islam yang dapat dinikmati dan didengarkan oleh mad'u.

Proses dakwah KH. Miftachul Munir dalam membina akhlak santri berawal dari usaha beliau mendirikan pondok pesantren As-Salim sebagai wadah pengkajian ilmu agama serta sarana pembinaan akhlak yang kian memburuk di daerah tersebut. Selain itu pesntren $A s^{-}$ Salim didirikan untuk memfasilitasi anak terlantar dan yatim piatu agar mereka memiliki harapan kembali untuk menyongsong masa depan yang cerah. Dalam dakwahnya beliau mengarahkan santri menuju kebaikan melalui pengajaran media seni. Santri yang berlatar belakang badboy atau istilah beliau adalah anak ilalang (yatim piatu) cenderung sulit jika hanya diarahkan melalui nasihat lisan saja. Mereka butuh sesuatu yang bisa menarik perhatian dan sesuatu yang menyenangkan, salah satunya dengan megajarkan mereka seni musik dan seni lukis islami. Melalui media seni itulah beliau mulai mengarahkan mereka pada jalan yang benar, memperkenalkan Allah lebih dekat lagi, dan memberikan ruh-ruh Islam di setiap mengajarkan seni musik dan seni lukis. Ungkapan KH. Miftachul Munir tentang membina akhlak santrinya melalui media dakwah seni sebagai berikut.

Banyak orang yang tidak sanggup menampung anak-anak yang terlantar. Kalau bukan orang dunia seni tidak akan telaten. Kalau kita cuma sekadar menampung dan diarahkan untuk ngaji saja itu kurang efektif. Jika tidak didasari niat ibadah, atau merasa keberatan dalam membina anak ilalang (sebutan beliau untuk anak terlantar/ yatim piatu) lebih baik nyantuni (memberi uang) saja. Dengan media yang saya gunakan ini, anak-anak lebih termotivasi dalam mengembangkan bakat. Mereka akan lebih efektif jika dikendalikan kenakalannya dengan praktik bermain musik atau seni lainnya daripada sekadar diceramahi. Ini sudah saya buktikan bahwa dulu anak yang hanya dilihat sebelah mata oleh masyarakat karena kenakalannya ternyata mampu menjuarai lomba Nasyid setelah saya bimbing. Artinya apa? Setiap anak pasti memiliki bakat, jika ada yang mengarahkan. Tidak perlu kita capek-capek menyuruh mereka untuk taubat, cukup dengan mengarahkan saja itu lebih efektif menurut saya.

Lebih lanjut, KH. Miftachul Munir mengemukakan bahwa media dakwah seni mampu membesarkan hati anak-anak. Jika dulu mereka merasa bahwa hidupnya sudah tidak ada gunanya lagi, tetapi setelah diarahkan pada seni, ternyata mereka mampu. "Sehitam apapun masa lalu mereka, dengan melukis, saya bantu mereka memberikan warna-warni untuk menghapus warna hitam dibelakangnya," KH. Miftachul Munir menjelaskan. Setelah mereka tahu akan bakatnya masingmasing, mereka akan menemukan Allah SWT. Selama ini, Allah itu ada, Allah selalu memberikan jalan kepada mereka yang mencari kebenaran (KH. Miftachul Munir, Wawancara, 4 Desember 2018).

Kaitan antara media dakwah seni dengan pembinaan akhlak santri tentu amat sangat berkaitan. Hal ini dapat dilihat dengan penerapan media dakwah seni di pondok pesantren seni As-Salim dalam membina akhlak santri. Seperti yang dipaparkan diatas, bahwa membina akhlak santri, yang pada dasarnya adalah anak terlantar dan cenderung berkarakter badboy, mereka lebih mudah ditakhlukkan 
dengan pendekatan berupa hal yang mereka suka, seperti seni musik dan seni lukis. Daripada hanya sekedar memberikan ceramah, yang cenderung masuk telinga kiri, dan keluar telinga kanan, mereka lebih antusias jika model dakwah yang kita sajikan dapat menarik perhatian mereka. Jika mereka para santri telah antusias dan tertarik dengan apa yang kita ajarkan, maka sedikit demi sedikit nilai-nilai keislaman akan mudah dimasukkan, dan dengan demikian proses pembentukan akhlak semakin mudah terwujud. Dari sini kemudian KH. Miftachul Munir bisa membentuk karakter mereka melalui mauidloh hasanah (nasihat yang baik) serta sindiran-sindiran berupa guyonan untuk menyadarkan santrinya tentang perilaku mereka yang salah. Ungkapan KH. Miftachul Munir tentang membina akhlak santri.

Saya bisa dikatakan cukup berhasil membina mereka dikarenakan faktor pengalaman pribadi saya. Dulu, saya juga pernah nakal, makanya saya bisa memahami kenakalan mereka. Dulu, saya juga pernah terpuruk seperti mereka. Artinya, keberhasilan itu dapat diraih setelah proses kegagalan. Salain itu, dari sisi materi yang dititipkan Allah pada pesantren ini juga mendukung dalam membina akhlak mereka. Karena selain butuh pembinaan, mereka santri yatim piatu juga butuh materi berupa uang saku dan uang jajan. Dari keluarga pribadi ,memang materi alhamdulillah sudah bisa dikatakan cukup untuk membina anak ilalang ini. Dan dari para donatur juga, alhamdulillah, tidak ada putusnya. "Allah Maha Kaya". Namun, di antara keberhasilan itu, memang sebanding dengan apa yang kita usahakan karena yang kita hadapi adalah anak-anak ilalang (badboy) tadi. Maka, hambatannya adalah saya, sebagai guru mereka, harus mengalah dengan keinginan mereka, yakni mengikuti kemauannya terlebih dahulu sebelum kita mengarahkan. Kemudian, kewibawaan guru sementara ditanggalkan. Jadi, antara saya dengan santri itu sederajad (tidak ada sekat) agar saya dapat memahami karakter mereka. Selain itu, banyak waktu yang harus di luangkan dan juga perlu biaya dan tenaga ekstra untuk membina mereka. Dan semua itu, akan terasa mudah jika didasari niat ibadah. Selain itu, juga perlu kesabaran. Segala sesuatu tidak ada yang instan, perlu proses dan rintangan pasti ada. Kemudian ikhlas, semua yang kita kerjakan, seberat apapun kalau didasari rasa ikhlas akan terasa enteng (ringan). Dan yang terakhir adalah optimis. Sebelum meyakinkan orang lain kita harus yakin dulu dengan diri kita. Yakinlah...Sesuatu yang buruk belum tentu tetap buruk dimasa yang akan datang!!” (KH. Miftachul Munir, Wawancara, 4 Desember 2018)

Dalam membina akhlak santri, KH. Miftachul Munir menganggap santrinya seperti anaknya sendiri. Beliau mendidik penuh dengan kasih sayang dan juga ketegasan. Jika ada santrinya yang kembali ke jalan yang salah, maka beliau tidak segan-segan memberikan peringatan keras. Selain santri ilalang, beliau juga menerima siapa saja yang ingin memperdalam ilmu kesenian di pondok pesantren As-Salim ini. KH. Miftachul Munir tidak hanya sekedar mengajarkan kesenian kemudian setelah bisa dan terampil dibiarkan, tidak. Tetapi beliau juga memberikan kesempatan santrinya untuk menunjukkan kemampuan bakat-nya dihadapan masyarakat. Biasanya, ketika beliau mendapat undangan untuk mengisi mau'idloh hasanah, beliau juga mempromosikan bahwa santrinya ada yang bisa bermain musik nasyid dan banjari. Sehingga santri As-Salim menjadi incaran yang dipercaya untuk mengisi 
acara-acara tertentu. Bahkan jika ada lomba-lomba, beliau langsung mendaftarkan murid-muridnya agar kemampuan yang dimiliki semakin berkembang. Dengan demikian, para santri akan lebih giat berlatih setiap harinya. Sehingga, ketika mereka mulai disibukkan dengan kegiatan positif seperti itu, maka mereka tidak akan mudah terjerumus pada perilaku kenakalan remaja seperti diluar pesantren. Ungkapan menantu KH. Miftachul Munir, yang dulunya juga menjadi santri dan sekaligus menantu.

Saya masih ingat ketika saya masih duduk di bangku SD, saya sering melihat banyak anak sedang berlatih menabuh banjari. Diamdiam saya memperhatikan latihan itu hampir setiap hari. Pada suatu hari, KH. Miftachul Munir melihat keberadaan saya, dan memanggil saya untuk ikut bergabung berlatih banjari. Semenjak itu, saya menjadi santri beliau, rumah saya yang tidak jauh dari lokasi As-Salim membuat saya semakin rajin ikut latihan banjari. Saya juga kerasan berada di As-Salim karena keramahan beliau pada santrinya dan menganggap santri sebagai anaknya sendiri. Kedekatan yang belum pernah saya dapat dari siapapun kecuali orangtua kandung saya. Namun, ketika saya salah, beliau juga tidak segan-segan bertindak tegas pada santrinya termasuk saya. Bagi saya, media seni ini lebih efektif dan bisa diterima santri dalam pembinaan akhlak ketimbang hanya melalui nasihat atau ceramah saja. Dari media seni itulah beliau memberikan ruh-ruh Islam pada setiap pengajarannya. (Ridwan Faqih, (menantu KH. Miftachul Munir), Wawancara, 5 Desember 2018)
Faqih menyebutkan bahwa apa yang senantiasa diungkapkan oleh $\mathrm{KH}$. Miftachul Munir bahwa "ketika kita bersholawat banjari, bermain nasyid, atau melukis kaligrafi, dan setiap nada yang kita keluarkan, pukulan yang kita tabuhkan, goresan yang kita lukiskan disitulah kita mengingat Allah (dzikrullah)". Di sini, seni telah menstransformasikan diri ke dalam medium dakwah. Medium seni tidak lagi merepresentasikan diri semata sebagai hiburan atau sekadar ekspresi budaya, tapi telah menjadi medium pengingat Allah. Seni dengan demikian memancarkan spiritualitasnya.

Media seni masih sangat jarang diaplikasikan oleh khalayak dalam pembinaan akhlak santri atau digunakan sebagai medium dakwah meskipun telah lama dirintis oleh para wali. KH. Miftachul Munir sebenarnya terinspirasi oleh $\mathrm{KH}$. Khumaidi (termasuk kerabat) yang menerapkan media dakwah ini kepada santrinya melalui musik nasyid dan banjari di daerah makam Sunan Ampel Surabaya. Selain itu, media dakwah seni mampu membesarkan hati para santri. Jika dulu mereka merasa bahwa hidupnya sudah tidak ada gunanya lagi, tetapi setelah diarahkan pada seni, ternyata mereka mampu. Setelah mereka tahu akan bakatnya masing-masing, maka disana mereka akan menemukan Allah. Bahwa selama ini Allah itu ada, Allah selalu memberikan jalan kepada mereka yang mencari kebenaran. Dari situlah, mereka dibimbing untuk mensyukuri nikmat Allah berupa bakat dan kemampuan yang mereka miliki. Yang mana itu semua semata-mata adalah karunia Allah Swt. Hal yang dilakukan oleh KH. Miftahul Munir ini merupakan sebuah motivasi kepada santrinya agar terus mengembangkan bakatnya dengan selalu optimis akan pertolongan Allah SWT. sesuai dengan firman Allah, "Dan jangan kamu berputus asa dari rahmat Allah. Sesungguhnya 
tiada berputus asa dari rahmat Allah, melainkan kaum yang kafir". (QS. Yusuf: 87).

Dengan media dakwah ini, para santri yang dulu dipandang sebelah mata oleh masyarakat karena kenakalannya sekarang mulai hilang sedikit demi sedikit. Seringkali grup nasyid yang dibentuk oleh mereka menjuarai perlombaan. Hal ini membuktikan bahwasannya kenakalan remaja itu terjadi atas kekosongan dan pikiran yang kosong. Sehingga syetan mudah masuk dan menjerumuskannya. Akan tetapi ketika mereka diberi kesibukan berupa hal-hal yang mereka suka, tanpa disadari kenakalan mereka hilang sedikit demi sedikit. Dan tentunya itu semua perlu adanya bimbingan dari sosok seorang guru. Kekurangannya adalah tidak semua da’i mampu menerapkan seperti dakwah yang dilakukan oleh KH. Miftachul Munir. Dibutuhkan pengetahuan dan skill yang bagus dalam penguasaan bidang seni.

Maka, dakwah KH. Miftachul Munir ini sesuai dengan teori pembaruan agama yang dikemukakan oleh Yusuf Qordlowi. Pertama, dalam hal mengarahkan bukan mengubah. Dalam teori pembaruan agama Yusuf Qordlowi, dikemukakan sebagai berikut.

Pembaruan terhadap sesuatu bukan berarti anda menghilangkan dan mendirikan sesuatu yang baru untuk menggantikannya. Ini sama sekali bukan termasuk pembaruan. Pembaruan adalah anda membiarkannya pada inti, identitas dan karakteristiknya tetapi anda memperbaiki yang usang, memperkuat sisi-sisinya yang lemah, sebagaimana ketika anda hendak memperbarui mesjid bersejarah atau istana bersejarah.
Hal ini diterapkan KH. Miftachul Munir dalam membina akhlak santri. Beliau senantiasa mengikuti kemauan santrinya, kemudian beliau hanya mengarahkan mereka dengan bakat seninya. Sesuai dengan karakter santri dan sama sekali tidak mengubah karakter santri, melainkan menghias dan memperkuat dengan sentuhan seni Islami.

Kedua, menggali potensi bukan mendoktrin. Yusuf Qordlowi dalam ini mengatakan sebagai berikut.

Pembaruan agama harus dari dalam dengan alat-alatnya yang syar'i melalui para penganutnya dan ulamanya, bukan dengan cara merongrongnya, bukan dengan menindas penganutnya, bukan pula dengan memasukkan unsur-unsur asing ke dalamnya dan memaksakannya dengan kekerasan.

Pernyataan tersebut sinkron dengan dakwah KH. Miftachul Munir yang sama sekali tidak ada paksaan, melainkan hanya arahan dan bimbingan dalam membina akhlak santrinya. KH. Miftachul Munir mencoba menggali bakat dan karakter para santri agar dapat dikembangkan. Jadi, sama sekali tidak ada unsur-unsur asing yang dimasukkan kepada santrinya.

\section{Kesimpulan}

Berdasarkan penelitian yang dilakukan dan diuraikan dalam pembahasan, peneliti menarik dua kesimpulan mendasar. Pertama, aktivitas KH. Miftachul Munir melalui pendirian pondok pesantren As-Salim dan pemanfaatan media seni dalam berdakwah bertujuan untuk mewujudkan wadah pengkajian ilmu agama serta sarana pembinaan akhlak yang kian memburuk di daerah tersebut. Selain itu pesantren $A s-$ 
Salim didirikan untuk memfasilitasi anak terlantar dan yatim piatu agar mereka memiliki harapan kembali untuk menyongsong masa depan yang cerah. Dalam dakwahnya beliau mengarahkan santri menuju kebaikan melalui pengajaran media seni. Santri yang berlatar belakang badboy atau istilah beliau adalah anak ilalang (yatim piatu) cenderung sulit jika hanya diarahkan melalui nasihat lisan saja. Mereka butuh sesuatu yang bisa menarik perhatian dan sesuatu yang menyenangkan, salah satunya dengan mengajarkan mereka seni musik dan seni lukis islami.

Kedua, kelebihan media dakwah seni adalah masih sangat jarang diaplikasikan oleh khalayak dalam pembinaan akhlak santri. Media dakwah seni beliau sebut sebagai media pencuri hati para santri. Jadi, apa yang sekiranya santri senangi beliau ikuti dulu kemauannya selama tidak keluar dari syari'at agama. Sedangkan kekurangannya adalah tidak semua da` mampu menerapkan seperti dakwah yang dilakukan oleh KH. Miftachul Munir. Dibutuhkan pengetahuan dan skill yang bagus dalam penguasaan bidang seni. Bagi para peneliti yang akan meneliti komunikasi dakwah, bisa menggali lebih mendalam tentang perilaku santri setelah menerima media dakwah seni dari $\mathrm{KH}$. Miftachul Munir. Supaya penelitian ini dapat lebih berkembang dan mendapat hasil yang optimal.

\section{Daftar Pustaka}

Alwan, Khoiri. (2005). Akhlak Tasawuf. Yogyakarta: Pokja UIN Sunan Kalijaga.

Amin, Samsul Munir. (2008). Rekonstruksi Pemikiran Dakwah Islam. Jakarta.

Amstrong, Amatullah. (1996). Khasanah Istilah Sufi (Kunci memasuki dunioa tasawuf). Bandung: Mizan.

Aras, Ahmad. (2006). Paradigma Dakwah Kontemporer. Semarang: Walisongo Press IAIN Walisongo.

Aziz, Moh Ali. (2004). Ilmu Dakwah. Jakarta: Kencana.

Cangara, Hafied. (2000). Pengantar Ilmu Komunikasi. Jakarta: PT. Raja Grafindo.
Departement Pendidikan dan Kebudayaan. (1994). Kamus Besar Bahasa Indonesia. Jakarta: Balai Pustaka.

Enjang. (2009). Dasar-Dasar Ilmu Dakwah. Bandung.

Hafidhuddin, Didin. (1998). Dakwah Aktual. Jakarta: Gema Insani.

Hawa, Said. (2004). Al-Mustakhlas fi Tazkiyah al-Anfus, Cetakan ke 8 , Terj.Annur Rafiq Shaleh Tahmid. Jakarta: Rabani Press.

Ilyas, Yanuar. (2005). Kuliah Akhlaq. Yogyakarta: Lembaga Pengkajian dan Pengamalan Islam(LPPI).

Moleong, Lexy J. (2003). Metode Penelitian Kualitatif. Bandung: PT. Remaja Rosdakarya. 
(2007). Metode Penelitian Kualitatif. Bandung: PT. Remaja Rosdakarya.

Muriah, Siti. (2000). Metodologi Dakwah Kontemporer. Yogyakarta: Mitra Pustaka.
Qordhowi, Yusuf. (2001). Kebudayaan Islam Eksklusif atau Inklusif. Solo: Era Intermedia.

Sugiyono. (2008). Metode Penelitian Kuantitatif Kualitatif dan $R \& D$. Bandung: Alfabeta. 